\title{
Penggunaan Media Pembelajaran Petak Persegi Untuk Meningkatkan Aktivitas Belajar Dan Hasil Belajar Materi Bangun Datar
}

\section{Devi Luxvia Rizqiana}

Universitas Sebelas Maret

deviluxrizqiana116@gmail.com

\section{Article History}

received 30/4/2021

\begin{abstract}
The low activity and learning outcomes of students in the flat shape material is caused by the lack of teacher innovation in packaging learning. The purpose of this study was to determine the use of square- plot learning media in increasing learning activities and student learning outcomes on flat-shaped materials. The research conducted was Classroom Action Research (CAR) in two cycles, with each cycle consisting of two meetings. The stage of each cycle are planning, implementation, observastion and reflection. In cycle 1 the average percentage of student activity is 64,28\%. In cycle 2 the percentage of student activity increased to $80,00 \%$. While the learning outcomes in cycle 1 the percentage of classical learning completeness is $78,57 \%$, while in cycle 2, the percentage of classical learning completeness is $85,71 \%$. The results indicate that the use of square grid media can improve learning activities and student learning outcomes on flat- shaped materials.
\end{abstract}

Keywords: Square grid learning media, learning activities, learning outcomes, two-dimentional figure

\begin{abstract}
Abstrak
Rendahnya aktivitas dan hasil belajar peserta didik dalam materi bangun datar disebabkan oleh kurangnya inovasi guru dalam mengemas pembelajaran. Tujuan dari penelitian ini adalah untuk mengetahui penggunaan media pembelajaran petak persegi dalam peningkatan aktivitas belajar dan hasil belajar peserta didik pada materi bangun datar. Penelitian yang dilakukan adalah Penelitian Tindakan Kelas (PTK) sebanyak dua siklus, dengan setiap siklusnya terdiri dua pertemuan. Adapun tahapan setiap siklus yaitu perencanaan, pelaksanaan, observasi dan refleksi. Pada siklus 1 rata- rata presentase aktivitas peserta didik sebesar $64,28 \%$. Pada siklus 2 presentase aktivitas peserta didik meningkat menjadi 80,00\%. Sedangkan pada hasil belajar siklus 1 presentase ketuntasan belajar klasikal yaitu $78,57 \%$, sedangkan pada siklus 2 diperoleh prsentase ketuntasan belajar klasikal $85,71 \%$. Hasil ini menunjukkan bahwa penggunaan media petak persegi dapat meningkatkan aktivitas belajar dan hasil belajar peserta didik pada materi bangun datar.
\end{abstract}

Kata kunci: media pembelajaran petak persegi, aktivitas belajar, hasil belajar, bangun datar 


\section{PENDAHULUAN}

Pembelajaran matematika menjadi salah satu mata pelajaran yang wajib di kuasai oleh peserta didik selama belajar di sekolah. Peserta didik diharapkan mampu dalam memecahkan berbagai persoalan pada soal matematika dan menerapkannya dalam kehidupan sehari- hari. Selain itu, peserta didik harus mampu mengembangkan kemampuannya dan mempunyai karakter sesuai dengan tujuan pendidikan yang terdapat pada Undang- Undang Republik Indonesia Nomor 20 Tahun 2003 pasal 3 tentang Sistem Pendidikan Nasional yang menyatakan fungsi dan tujuan pendidikan nasional.

Pembelajaran bukan hanya sekedar memindahkan pengetahuan dari guru kepada peserta didik. Akan tetapi memfasilitasi peserta didik agar dapat memaknai suatu proses dalam belajarnya. Hal ini sejalan dengan teori konstruktivisme. Pandangan kontruktivistik mengemukakan bahwa belajar merupakan usaha pemberian makna oleh peserta didik kepada pengalamannya melalui asimilasi dan akomodasi yang menuju pada pembentukan struktur kognitifnya, memungkinkan mengarah kepada tujuan tersebut (Malawi, 2015). Dalam pembelajaran matematika peserta didik dilatih agar dapat berfikir secara logis dalam menyelesaikan suatu permasalahan. Namun pada kenyataanya, mata pelajaran matematika sendiri dianggap sebagai mata pelajaran yang menakutkan dan sulit bagi peserta didik. Banyak peserta didik yang kurang aktif selama mengikuti proses pembelajaran.

Berdasarkan observasi di SDN Jambeyan 3 , Sambirejo, Sragen, nilai peserta didik masih terbilang rendah pada materi bangun datar yang didasarkan pada penilaian harian di bawah KKM yaitu 65. Banyak kendala yang dihadapi dalam pembelajaran matematika, khususnya pada materi bangun datar di kelas 3 . Kendala yang sering terjadi selama proses pembelajaran pada mata pelajaran matematika ialah guru terlalu menuntut peserta didik untuk menyelesaikan soal- soal pada buku ataupun LKS. Guru tidak memberi kesempatan kepada peserta didik untuk berperan aktif dalam menggali dan menganalisis informasi yang berkaitan pada suatu materi yang diberikan oleh guru tersebut. Sehingga peserta didik mengalami kejenuhan dalam belajar. Banyak peserta didik mengalami kebingungan untuk menyelesaikan persoalan yang dihadapi terkait dengan materi bangun datar. Bangun datar dapat didefiniskan sebagai bangun yang mempunyai dua dimensi yaitu panjang dan lebar tetapi tidak mempunyai tinggi dan tebal (Rahaju, dalam Een dkk, 2020). Artinya, bahwa bangun datar hanya mempunyai panjang dan lebar. Bangun datar adalah suatu bentuk dua dimensi yang memiliki materidan keliling, namun tidak memiliki ruang.

Guru dalam mengemas pembelajaran juga kurang berinovasi. Pembelajaran masih terpusat pada guru atau teacher center dimana guru hanya menerangkan lalu memberi tugas pada peserta didik untuk mengerjakan soal. Untuk itu, guru perlu meningkatkan kekreativitasan dalam merancang sebuah media pembelajaran yang menarik dan menyenangkan dalam proses pembelajaran. Media pembelajaran adalah sesuatu yang digunakan dalam kegiatan pembelajaran yang berfungsi untuk menyampaikan isi materi pembelajarann dan dapat membangun kondisi yang membuat peserta didik mampu memperoleh pengetahuan, keterampilan, atau sikap (Lestiana dan Rini, 2016). Sehingga melalui media pembelajaran tersebut dapat memotivasi peserta didik selama mengikuti kegiatan pembelajaran.

Penggunaan media pembelajaran dapat dijadikan solusi untuk meningkatkan aktivitas belajar dan hasil belajar peserta didik. Aktivitas belajar merupakan suatu kegiatan yang dilakukan untuk menghasilkan perubahan pengetahuan- pengetahuan, nilai- nilai sikap, dan keterampilan pada peserta didik sebagai latihan yang dilaksanakan secara sengaja. (Hasmiati dkk, 2017). Sedangkan hasil belajar merupakan pencapaian bentuk perubahan perilaku yang cenderung menetap dari ranah kognitif, afektif, dan psikomotoris dari proses belajar yang dilakukan dalam 
waktu tertentu (Jihad \& Haris, 2012). Hasil belajar merupakan perubahan yang muncul akibat dari proses belajar yang telah dilakukan oleh peserta didik.

Salah satu media pembelajaran yang dapat diterapkan untuk mengatasi kesulitan peserta didik dalam memahami materi materi bangun datar adalah media petak persegi. Media petak persegi merupakan alat alat peraga yang terbuat dari bahan kertas tebal berbentuk persegi dan persegi panjang (Fitria dan Budiyono, 2017). Media petak persegi satauan memiliki kelebihan sebagai berikut: 1) Media petak persegi mudah dalam penggunaannya dan peserta didik dengan cepat memahami materi yang disampaikan oleh guru; 2) Media petak persegi mudah dibawa dan dipindahkan; 3) Peserta didik menjadi lebih tertarik dan lebih semangat daalam menerima materi pembelajaran karena desain media yang berwarna warni; 4) IImu yang akan diterima akan tahan lama karena peserta didik dapat belajar sambil bermain karena media petak persegi dapat mengkonkretkan peserta didik dalam memahami konsep dasar serta rumus keliling, materipersegi dan persegi panjang. (Fitria dan Budiyono, 2017). Pada penelitian ini peneliti meneliti penggunaan media pembelajaran petak persegi, apakah penggunaan media pembelajaran petak persegi dapat meningkatkan aktivitas belajar materi bangun datar peserta didik kelas 3 SD Negeri Jambeyan 3 dan apakah penggunaan media pembelajaran petak persegi dapat meningkatkan hasil belajar materi bangun datar pada peserta didik kelas 3 SD Negeri Jambeyan 3. Peneliti meneliti hasil belajar pada aspek pengetahuan.

Berdasarkan uraian di atas tujuan penelitian ini yaitu untuk mengetahui penggunaan media pembelajaran petak persegi dapat meningkatkan aktivitas belajar materi bangun datar pada peserta didik kelas 3 SDN Jambeyan 3, Kecamatan Sambirejo, Kabupaten Sragen dan untuk mengetahui penggunaan media pembelajaran petak persegi dapat meningkatkan hasil belajar materi bangun datar pada peserta didik kelas 3 SD 3 SDN Jambeyan 3, Kecamatan Sambirejo, Kabupaten Sragen.

\section{METODE}

Penelitian ini adalah penelitian tindakan kelas (PTK) dengan menggunakan media pembelajaran petak persegi. Langkah- langkah PTK dibagi menjadi empat tahap yaitu tahap pertama adalah rencana kegiatan, tahap kedua adalah pelaksanaan tindakan, tahap ketiga yaitu observasi atau evaluasi, dan tahap selanjutnya adalah tahap refleksi. (Pramestya dkk, 2015). Penelitian ini dilaksanakan dalam rentang waktu kurang lebih 6 bulan, dari bulan Januari hingga bulan Juli. Penelitian ini dilaksanakan selama dua siklus. Siklus 1 dilaksanakan pada tanggal 12 Maret 2021 dan 20 Maret 2021. Sedangkan siklus 2 dilaksanakan pada tanggal 29 April 2021 dan 6 Mei 2021. Subjek penelitiannya yaitu peserta didik kelas 3 SDN Jambeyan 3 Kecamatan Sambirejo, Kabupaten Sragen Tahun Ajaran 2020/2021. Teknik pengumpulan data yang dilakukann dengan observasi, tes, dan dokumentasi. Observasi meliputi observasi pada aktivitas peserta didik terhadap pembelajaran menggunakan media petak persegi. Sedangkan untuk hasil belajar menggunakan tes tulis. Analisis penelitian ini adalah data kuantitatif dan kualitatif. Teknik kuantitatif digunakan untuk memperoleh hasil tes yang digunakan untuk menentukan peningkatan pemahaman materi materibangun datar matematika, sedangkan data kualitatif digunakan untuk menganalisis data yang diperoleh dari observasi dan dokumentasi

\section{HASIL DAN PEMBAHASAN}

Pada siklus 1 pembelajaran dilaksanakan selama dua pertemuan, setiap pertemuan diadakann post test untuk mengetahui peningkatan hasil belajar peserta didik. Selain itu, peneliti juga mengobservasi aktivitas peserta didik melalui lembar observasi di setiap pertemuan untuk mengetahuai peningkatan aktivitas belajar peserta didik. Siklus 1 membahas materi tentang luas bangun datar menggunakan media petak 
Volume 9 Nomor 1 Tahun 2021

persegi. Berikut ini adalah aktivitas belajar peserta didik dan hasil belajar peserta didik pada Siklus 1 yang dapat dilihat pada tabel.

Tabel 1. Aktivitas Belajar Peserta Didik Siklus 1

\begin{tabular}{llcccc}
\hline \multirow{2}{*}{ No } & \multicolumn{1}{c}{ Indikator } & \multicolumn{2}{c}{ Pertemuann 1 } & \multicolumn{2}{c}{ Pertemuan 2 } \\
& & Skor & Persentase & skor & Persentase \\
\hline 1 & Keaktifan mengikuti & 34 & $60,71 \%$ & 35 & $62,50 \%$ \\
2 & pelajaran & 36 & $64,28 \%$ & 38 & $67,85 \%$ \\
3 & Menyimak penjelasan & 36 & $64,28 \%$ & 38 & $67,85 \%$ \\
4 & Tandiskusi & 41 & $73,21 \%$ & 44 & $78,57 \%$ \\
5 & Partisipasi menyelesaikan & 43 & $76,78 \%$ & 44 & $78,57 \%$ \\
& soal & & $67,85 \%$ & & $71,07 \%$ \\
\hline
\end{tabular}

Berdasarkan tabel di atas, terjadi peningkatan aktivitas belajar peserta didik antara pertemuan 1 dengan pertemuan 2. Pada pertemuan 1 rata- rata persentase dari ke lima indikator sebanyak 67,85\%, sedangkan pada pertemuan 2 rata- rata persentase sebanyak $71,07 \%$. Hal ini membuktikan bahwa terjadi peningkatan pada setiap pertemuan di Siklus 1 .

Sedangkan hasil belajar peserta didik pada siklus 1 dapat dilihat berdasarkan tabel berikut ini.

Tabel 2. Hasil Belajar Peserta Didik Siklus 1

\begin{tabular}{ccccc}
\hline \multirow{2}{*}{ Siklus 1 } & \multicolumn{2}{c}{ Peserta didik Tuntas } & \multicolumn{2}{c}{ Peserta Didik belum tuntas } \\
& Jumlah & Persentase & Jumlah & Persentase \\
\hline Pertemuan 1 & 9 & $64,28 \%$ & 5 & $35,71 \%$ \\
Pertemuan 2 & 11 & $78,57 \%$ & 3 & $21,14 \%$ \\
\hline
\end{tabular}

Berdasarkan tabel di atas, telah terjadi peningkatan hasil belajar peserta didik yang tuntas pada pertemuan 1 dengan pertemuan 2. Ketuntasan klasikal pada tiap pertemuan juga mengalami peningkatan. Pada pertemuan 1 diperoleh sembilan peserta didik yang memenuhi KKM sebesar 65 dengan presentase ketuntasan klasikal sebesar $64,28 \%$, sedangkan lima peserta didik belum memenuhi KKM memperoleh presentase $35,71 \%$. Demikian juga dengan pertemuan 2 yang mengalami peningkatan ketuntasan klasikal dari pertemuan 1. Sebanyak sebelas peserta didik memenui nilai KKM dengan presentase ketuntasan klasikal sebanyak $78,57 \%$, sedangkan tiga peserta didik belum memenuhi KKM memperoleh presentase ketuntasan 21,14\%.

Setelah melakukan refleksi pada siklus 1, maka di putuskan untuk melanjutkan penelitian pada siklus 2. Hal ini dikarenakan pada siklus 1 belum mencapai indikator kinerja yang diharapkan. Pada siklus 2, membahas tentang materi keliling bangun datar menggunakan media petak persegi. Berikut ini adalah aktivitas belajar peserta didik dan hasil belajar peserta didik yang dapat diamati melalui tabel.

Tabel 3. Aktivitas Belajar Peserta Didik Siklus 2

\begin{tabular}{|c|c|c|c|c|c|}
\hline \multirow{2}{*}{ No } & \multirow{2}{*}{ Indikator } & \multicolumn{2}{|c|}{ Pertemuann 1} & \multicolumn{2}{|c|}{ Pertemuan 2} \\
\hline & & Skor & Persentase & skor & Persentase \\
\hline 1 & $\begin{array}{l}\text { Keaktifan mengikuti } \\
\text { pelajaran }\end{array}$ & 41 & $73,21 \%$ & 47 & $83,92 \%$ \\
\hline 2 & Menyimak penjelasan & 40 & $71,42 \%$ & 49 & $87,50 \%$ \\
\hline
\end{tabular}




\begin{tabular}{llcccc}
\hline 3 & Berdiskusi & 42 & $75 \%$ & 47 & $83,92 \%$ \\
4 & Tanya jawab & 44 & $78,57 \%$ & 47 & $83,92 \%$ \\
5 & Partisipasi menyelesaikan & 43 & $76,78 \%$ & 48 & $85,71 \%$ \\
& soal $\quad$ Jumlah rata- rata & & $75,00 \%$ & & $84,99 \%$ \\
\hline
\end{tabular}

Berdasarkan tabel di atas, terjadi peningkatan aktivitas belajar peserta didik antara pertemuan 1 dengan pertemuan 2. Pada pertemuann 1 rata- rata persentase dari ke lima indikator sebanyak $75,00 \%$, sedangkan pada pertemuan 2 rata- rata persentase sebanyak $84,99 \%$. Hal ini membuktikan bahwa terjadi peningkatan pada setiap pertemuan di Siklus 2.

Sedangkan hasil belajar peserta didik pada siklus 1 dapat dilihat berdasarkan tabel berikut ini.

Tabel 4. Hasil Belajar Peserta Didik Siklus 2

\begin{tabular}{ccccc}
\hline \multirow{2}{*}{ Siklus 1 } & \multicolumn{2}{c}{ Peserta didik Tuntas } & \multicolumn{2}{c}{ Peserta Didik belum tuntas } \\
& Jumlah & Persentase & Jumlah & Persentase \\
\hline Pertemuan 1 & 11 & $78,57 \%$ & 3 & $21,14 \%$ \\
Pertemuan 2 & 12 & $85,71 \%$ & 2 & $14,28 \%$ \\
\hline
\end{tabular}

Berdasarkan tabel di atas, telah terjadi peningkatan hasil belajar peserta didik yang tuntas pada pertemuan 1 dengan pertemuan 2. Ketuntasan klasikal pada tiap pertemuan juga mengalami peningkatan. Pada pertemuan 1 diperoleh sebelas peserta didik yang memenuhi KKM sebesar 65 dengan presentase ketuntasan klasikal sebesar $78,57 \%$, sedangkan tiga peserta didik belum memenuhi KKM memperoleh presentase $21,14 \%$. Demikian juga dengan pertemuan 2 yang mengalami peningkatan ketuntasan klasikal dari pertemuan 1. Sebanyak dua belas peserta didik memenui nilai KKM dengan presentase ketuntasan klasikal sebanyak $85,71 \%$, sedangkan dua peserta didik belum memenuhi KKM memperoleh presentase ketuntasan 14,28\%.

Adapun aktivitas belajar dan hasil belajar peserta didik pada materi bangun datar menggunakan media petak persegi peserta didik kelas 3 SD Negeri Jambeyan 3 dari siklus 1 dan siklus 2 , dapat dibandingan sebagaimana yang terlihat pada tabel berikut ini:

Tabel 5. Perbandingan Persentase Aktivitas Peserta Didik Siklus 1 dan Siklus 2

\begin{tabular}{llcc}
\hline No & \multicolumn{1}{c}{ Indikator } & Rata- Rata Siklus 1 & Rata- Rata Siklus 2 \\
\hline 1 & Keaktifan dalam mengikuti & $61,61 \%$ & $78,57 \%$ \\
& pelajaran & $66,07 \%$ & $79,46 \%$ \\
2 & Menyimak penjelasan guru & $66,07 \%$ & $79,46 \%$ \\
3 & Berdiskusi dengan teman & $75,89 \%$ & $81,25 \%$ \\
4 & Melakukan tanya jawab & $77,68 \%$ & $81,25 \%$ \\
5 & Partisipasi menyelesaikan soal & $69,46 \%$ & $80,00 \%$ \\
\hline
\end{tabular}

Berdasarkan tabel di atas, dapat dilihat peningkatan rata- rata aktivitas belajar peserta didik dalam pembelajaran di kelas. Pada siklus 1 diperoleh rata- rata aktivitas belajar peserta didik sebanyak $69,46 \%$ sedangkan pada siklus 2 mengalami peningkatan rata- rata dengan persentase $80,00 \%$. 
Tabel 6. Perbandingan Hasil Belajar Peserta Didik Siklus 1 dan Siklus 2

\begin{tabular}{cccccc}
\hline $\begin{array}{c}\text { Nilai } \\
\text { Rata- } \\
\text { rata }\end{array}$ & $\begin{array}{c}\text { Siklus 1 } \\
\text { Peserta } \\
\text { didik tuntas }\end{array}$ & Persentase & $\begin{array}{c}\text { Nilai Rata- } \\
\text { rata }\end{array}$ & $\begin{array}{c}\text { Siklus 2 } \\
\text { Peserta } \\
\text { didk tuntas }\end{array}$ & Persentase \\
\hline 66,53 & 9 & $64,28 \%$ & 76 & 12 & $85,71 \%$ \\
\hline
\end{tabular}

Tabel diatas menunjukkan bahwa telah terjadi peningkatan hasil belajar peserta didik dari siklus 1 dengan siklus 2. Pada siklus 1 jumlah nilai rata- rata peserta didik dari pertemuan 1 dan pertemuan 2 yaitu 66,53. Dari empat belas peserta didik, terdapat sembilan peserta didik yang memenuhi KKM dengan persentase kelulusan yaitu 64,28\%. Sedangkan pada siklus 2 jumlah nilai rata- rata meningkat menjadi 76. Terdapat dua belas peserta didik yang memenuhi KKM dengan persentase kelulusan $85,71 \%$. Berdasarkan data aktivitas peserta didik dan hasil belajar peserta didik dapat dinyatakan bahwa indikaator keberhasilan yang telah di tetapkan masing- masing sebesar $80 \%$ sudah terpenuhi. Hal ini juga berarti bahwa penelitian di akhiri pada siklus 2.

Dari dua siklus yang sudah dilaksanakan selama 4 kali pertemuan, dapat dipastikan bahwa penggunaan media pembelajaran petak persegi dapat meningkatkan aktivitas belajar peserta didik dan hasil belajar peserta didik pada materi bangun datar kelas 3 SD Negeri Jambeyan 3. Pada mata pelajaran matematika, peserta didik mengalami kesulitan dalam memahami suatu konsep. Konsep matematika terdiri atas konsep primer dan sekunder. Konsep primer berhubungan dengan simbol matematika, sedangkan konsep sekunder berhubungan dengan konsep matematika. Salah satu cara mengkomunikasikan konsep sekunder ialah memeragakan dengan contoh (Yuza, 2018). Solusi yang dapat dipilih oleh guru yaitu menggunakan sebuah media. Media bermanfaat dalam proses pembelajaran, karena dengan adanya media, proses pembelajaran akan menjadi menyenangkan serta efektif dikarenakan media bisa menumbuhkan motivasi belajar siswa serta mempermudah siswa dalam menerima pesan atau informasi (Irwanto dan Budiyono, 2014). Melalui media petak persegi, guru dapat memeragakan untuk mencari rumus bangun datar kepada peserta didik. Hal ini juga sejalan dengan teori bahwa kegunaan media petak persegi adalah untuk memahami konsep dasar rumus keliling dan luas persegi dan persegi panjang tingkat sekolah dasar (Fitria dan Budiyono, 2017). Selama pembelajaran menggunakan media petak persegi, guru dan peserta didik terlihat aktif dalam melakukan tanya jawab dan diskusi terkait materi bangun datar.

Di lihat dari data- data, dapat diketahui bahwa media petak persegi dapat meningkatkan aktivitas belajar dan hasil belajar peserta didik. Dengan meningkatnya aktivitas belajar peserta didik, maka hasil belajar peserta didik pun juga akan meningkat. Aktivitas belajar peserta didik yang rendah seringkali juga menyebabkan pemahaman dan penguasaan materi pembelajaran menjadi berkurang (Fahmi, dkk: 2018). Aktivitas belajar peserta didik di golongkan ke dalam beberapa hal sebagai berikut, aktivitas visual, aktivitas lisan, aktivitas mendengarkan, aktivitas gerak, aktivitas menulis (Usman, dalam Anugraheni dan Rahmadani, 2017). Pada penelitian ini aktivitas yang diamati selama proses pembelajaran dibagi menjadi 5 indikator yaitu keaktifan peserta didik dalam mengikuti pelajaran, menyimak penjelasan dari guru, kegiatan berdiskusi dengan teman, melakukan tanya jawab, dan partisipasi peserta didik dalam menyelesaikan soal bersama guru. Hasil penelitian ini juga sesuai dengan penelitian sebelumnya yang dilakukan oleh Fitria, I dan Budiyono (2017) yang membuktikan bahwa penggunaan media petak persegi satuan dapat meningkatkan hasil belajar dalam mata pelajaran matematika materi luas dan keliling bangun datar kelas III SD. 


\section{SIMPULAN}

Penggunaan media petak persegi dapat meningkatkan aktivitas belajar peserta didik dan hasil belajar peserta didik kelas 3 pada materi bangun datar. Penerapan media petak persegi mampu meningkatkan aktivitas belajar ditunjukkan dengan perolehan rata- rata persentase skor pada siklus 1 sebesar $64,28 \%$, sedangkan pada siklus 2 meningkat menjadi 80,00. Pada hasil belajar peningkatan ditunjukkan dengan persentase ketuntasan belajar klasikal pada siklus 1 sebesar $64,28 \%$ meningkat pada siklus 2 dengan persentase ketuntasan belajar klasikal sebesar 85,71\%. Peningkatan yang terjadi selama dua siklus dengan empat kali pertemuan dikarenakan peserta didik memahami konsep mencari keliling dan luas bangun datar melalui media konkrit yang dapat dipraktikkan langsung oleh peserta didik. Sehingga peserta didik memperoleh pengalaman dan pembelajaran yang bermakna. Peserta didik akan mudah dalam menghitung dan mencari keliling dan luas bangun datar dikarenakan mereka menemukan sendiri pengetahuan mereka saat mempraktikkan mencari rumus bangun datar menggunakan media petak persegi. Berdasarkan penelitian yang telah dilaksanakan, salah satu media pembelajaran yang harus digunakan oleh guru dalam mengejar materi bangunn datar adalah media petak persegi. Melalui media petak persegi, peserta didik dilatih untuk memahami konsep tentang rumus suatu bangun datar, sehingga akan lebih mudah di pahami oleh peserta didik.

\section{DAFTAR PUSTAKA}

Anugraheni, I \& Rahmadani, N. (2017). Peningkatan Aktivitas Belajar Matematika Melalui Pendekatan Problem Based Learning Bagi Siswa Kelas 4 SD. (https://ejournal.uksw.edu/scholaria/article/view/928, di unduh 20 Januari 2021)

Een, dkk. (2020). Teori Brunner pada Konsep Bangun Datar Sekolah Dasar. (https://ejournal.stitpn.ac.id/index.php/nusantara/article/download/840/577/, di unduh 1 April 2021)

Fahmi, dkk. (2018). Penerapan media persegi satuan dalam pembelajaran luas bangun datar di kelas IV SD Negeri 47 Banda Aceh. (http://download.garuda.ristekdikti.go.id/article.php?article $=852727 \&$ val=9420\&titl e=PENERAPAN\%20MEDIA\%20PERSEGI\%20SATUAN\%20DALAM\%20PEMBE LAJARAN\%20LUAS\%20BANGUN\%20DATAR\%20DI\%20KELAS\%20IV\%20\%20 SD\%20NEGERI\%2047\%20BANDA\%20ACEH, di unduh 1 Juli 2021).

Fitria, I.K \& Budiyono, H (2017). Penggunaan media petak persegi satuan untuk meningkatkan hasil belajar dalam mata pelajaran matematika materi luas dan keliling bangun datar kelas III SDN Tropodo 1 Sidoarjo. (https://www.neliti.com/publications/254620/penggunaan-media-petak-persegisatuan-untuk-meningkatkan-hasil-belajar-dalam-mat, di unduh 3 Maret 2021).

Hasmiati, dkk. (2017). Aktivitas dan Hasil Belajar Siswa Pada Pembelajaran Pertumbuhan dan Perkembangan dengan Metode Praktikum. (http://journal.uinalauddin.ac.id/index.php/biotek/article/download/3444/3239, diunduh 21 Januari 2021).

Irwanto, E \& Budiyono. (2014). Meningkatkan Hasil Belajar Luas Bangun Datar Dengan Menggunakan Media Karton Berpetak Pada Siswa Kelas VI. (https://ejournal.unesa.ac.id/index.php/jurnal-penelitian pgsd/article/view/12180/4612, di unduh 1 Juli 2021).

Jihad, A. \& Haris, A. (2012). Evaluasi Pembelajaran. Yogyakarta: Multi Pressindo.

Lestiana \& Rini, K. (2016). Alat Peraga Konsep Luas Bangun Datar. (https://journal.unnes.ac.id/sju/index.php/prisma/article/download/21423/10160/, di unduh 1 April 2021)

Malawi, I. (2015). Belajar dan Pembelajaran. Madiun: IKIP PGRI Madiun

Undang- undang Republik Indonesia. (2003) Undang- Undang RI Nomor, 20 Tahun 2003 pasal 3, tentang Sistem Pendidikan Nasional. 
Volume 9 Nomor 1 Tahun 2021

Pramestya dkk. (2015). Penerapan Model Pembelajaran Example Non Example Berbantu Media Gambar Untuk Meningkatkan Perkembangan Kognitif Anak Kelompok A TK Kumara Adi I Denpasar Selatan. (https://ejournal.undiksha.ac.id/index.php/JJPAUD/article/view/4968, di unduh 15 Januari 2021)

Yuza, A. (2018). Pembelajaran Luas Daerah Bangun Datar Di Sekolah Dasar. (https://jurnal.umsb.ac.id/index.php/menarailmu/article/download/861/772, unduh 1 Juli 2021). 